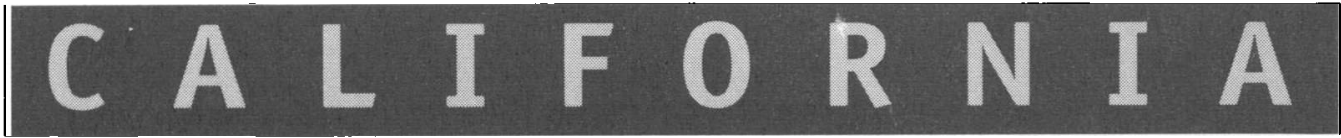

\section{The Middling Sort}

Commerce, Gender, and the Family in England, 1680-1780

\section{Margaret R. Hunt}

"A very full, nuanced, up-to-date, and lucidly expressed account. ... The discussion is impressively wide-ranging (spanning cultural, economic, intellectual, social, and women's history)."

- Johann Sommerville, University of Wisconsin-Madison

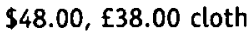

\section{Making Health Work}

Human Growth in Modern Japan Carl Mosk

Mosk's fine analysis shows how population quality provides a key to understanding economic growth and social change in Japan, a greatly changed and expanded society.

Studies in Demography, $\$ 45.00, \mathbf{\mp 3 5 . 0 0}$ cloth

\section{Fountain}

\section{of Fortune}

Money and Monetary Policy

in China, Tenth to

Seventeenth Centuries

\section{Richard von Glahn}

"A classic. All subsequent work in areas related to Chinese monetary history will simply have to follow in von Glahn's footsteps."-Dennis 0. Flynn, author of Born with a "Silver Spoon"

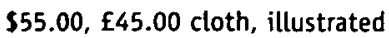

NEW IN PAPERBACK-

\section{Seducing the French}

The Dilemma of Americanization

Richard F. Kuisel

"A unique and pioneering fusion of political, economic, and mass cultural analysis. ... .

[Kuisel's] book should be required reading at the Federal Trade Commission."

-Diplomatic History

Winner, Chinard Prize and the New York State

Association for European Historians Prize for Best

Book in European History, \$15.95, £12.95 paper

\section{The Great}

Los Angeles Swindle

Oil, Stocks, and Scandal During the Roaring Twenties

Jules Tygiel

"For audacity, avarice, complexity, flamboyance and larceny, almost nothing compares to the tale told with hypnotic skill and splendid authority in Jules Tygiel's The Great Los Angeles Swindle."

$\$ 15.95$, £12.95 paper

-Washington Post Book World

\section{Dark Sweat, White Gold}

California Farm Workers, Cotton, and the New Deal

Devra Weber

"Belongs on the same shelf as Steinbeck's

The Grapes of Wrath and McWilliams' Factories in the Field."

-David Montejano, University of Texas $\$ 16.95$, f13.95 paper, illustrated

At bookstores or order US: 1-800-822-6657, UK: (1243) 842165. 


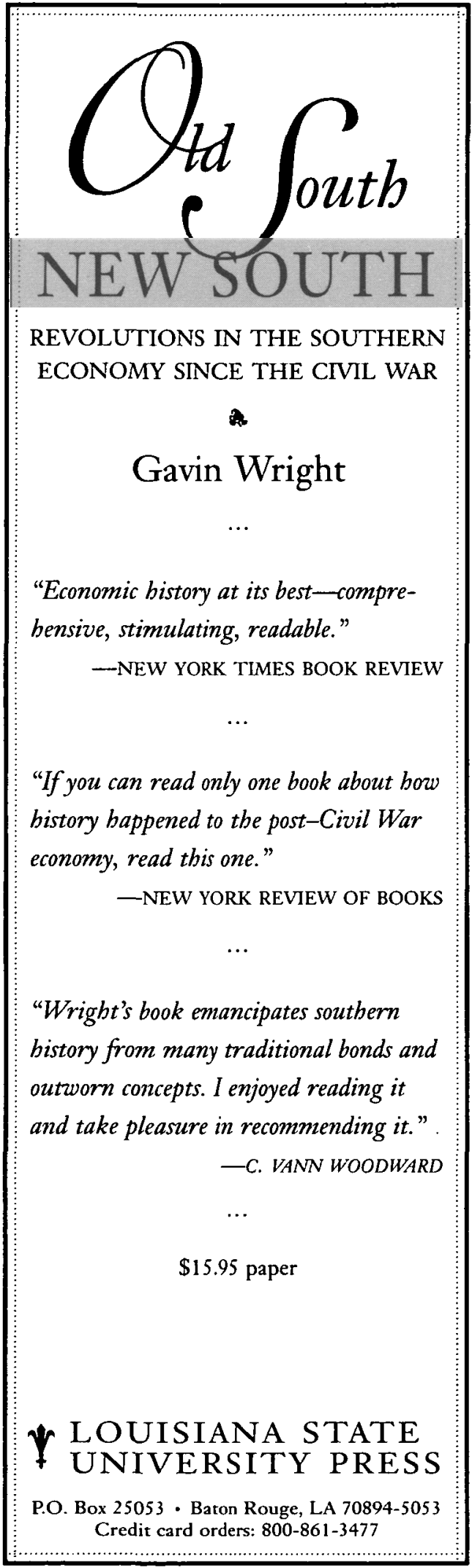




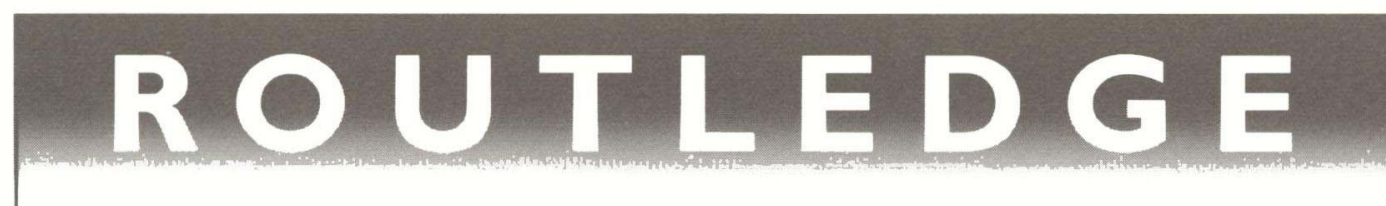

\section{The Dynamic Society}

Exploring the Sources of Global Change Graeme Donald Snooks

'Graeme Snooks' latest book is a tour de force of global economic history..."

- Baron Herman Van der Wee, Past President of the International Economic History Association

\section{$512 p p \quad \$ 24.95 / p b$}

\section{Colonialism and Development}

Britain and Its Tropical Colonies, 1850-1960

Edited by Michael A. Havinden

and David Meredith

Meredith provides a crucial background to understanding the present opportunities and difficulties facing the countries since their independence.

\section{$448 p p \quad \$ 22.95 / p b$}

\section{Consumption of Culture 1600-1800}

Image, Object, Text

John Brewer and Ann Bermingham

This is a radical new interpretation of early modern social history. The result is an important and rich new approach to the study of the 17th and 18th centuries.

\section{$672 p p \quad 115$ illus $\$ 150.00 / \mathrm{hb}$}

\section{Economic Ideas and Government Policy}

Contributions to Contemporary Economic History Sir Alec Cairncross

This collection of Cairncross' most important contributions to the economic history of the post-1939 period demonstrates a keen insight into the changing role of the economist and the transformation of the economic landscape.

296 pp $\$ 79.95 / h b$
Now in paperback

A Choice Outstanding Academic Book for 1994

\section{Maynard Keynes}

An Economists' Biography

D.E. Moggridge

"In all, Moggridge has given us a first-rate and indispensable addition to the growing literature on Keynes..."

- Journal of Economic Literature

976 pp 16 illus $\$ 27.95 / p b$

\section{The Economics of}

Joan Robinson

Edited by Maria Cristina Marcuzzo, Luigi Pasinetti, and Alesandro Reconcaglia

Robinson's work spanned six decades and is here analyzed by a distinguished, international team of scholars.

\section{4 pp $\quad \$ 79.95 / \mathrm{hb}$}

\section{Hayek's Political Economy \\ The Socio-economics of Order \\ Steve Fleetwood}

This book draws many of Hayek's insights together by locating them within newly emerging methodological perspective of critical realism and by scrutinizing the phenomena of knowledge and ignorance.

$192 p p \quad \$ 69.95 / h b$

\section{On The Origins of Classical Economics}

Distribution and Value from William Petty to Adam Smith Tony Aspromourgos

On the Origins of Classical Economics takes issue with the assumption that modern Economics began with Adam Smith and the publication of The Wealth of Nations and shows that the origins of classical economic theory have much deeper roots.

240 pp $\quad \$ 69.95 / h b$

*Prices subject to change. 


\section{NEW FROM CAMBRIDGE}

The Cambridge Economic Mistory of the United States

Vol. 1: The Colonial Era

\section{Stanley L. Engerman and}

\section{Robert E. Gallman, Editors}

This volume surveys the economic history of British North America, including Canada and the Caribbean. and of the early United States, from early settlement by Europeans to the end of the 18 th century.

Contributors: Neal Salisbury. John K. Thornton, E. L. Jones. David W. Galenson, Daniel Vickers, Russell R. Menard. B. W. Higman. John J. Mi Cusker, Cathy Matson 39442-2 Hardback \$74.95

\section{Networks of Innovation}

Vaccine Development at Merck, Sharp \& Dohme, and Mulford 1895-1995

\section{Louis Galambos}

\section{with Jane Eliot Sewell}

By surveying a century of innovation in biologicals, this book offers a historical perspective on the manner in which private sector organizations have acquired. periodically lost, and learned to sustain the ability to develop, manufacture, and market new serum antitoxins and vaccines.

56308-9 Hardback \$39.95

\section{Federal Taxation in America \\ A Short History \\ W. Elliot Brownlee}

This text describes the five principal stages of federal taxation in relation to the crises that led to their adoption-the formation of the Republic, the Civil War, World War I, the Great Depression, and World War II. It discusses the significant modification during the Reagan presidency of the last stage.

Woodrow Wilson Center Press Series

$\begin{array}{lll}56265-1 & \text { Hardback } & \$ 34.95 \\ 56586-3 & \text { Paperback } & \$ 12.95\end{array}$

\section{Funding the Modern American} State, 1941-1995

The Rise and Fall of the Era of Easy Finance

\section{W. Elliot Brownlee, Editor}

In this volume, an interdisciplinary group of scholars explores the history of American taxation and public finance since 1941 in an atrempt to understand the political, social and economic forces that have shaped the current regime.

Contributors: W. Flliot Brouenlee, Carolyn C. Jones l:dward D. Berkou'itz, Herhert Stein, Juian Zelizer. Catthie 1o Martin. C. Eingene Steuerle

Woodrow Wilson Center Press Series
55240-0
Hardback
$\$ 59.95$

Spanish Agriculture:

The Long Slesta, 1765-1965 James Simpson

Simpson argues that decisive changes in farming techniques only occurred at the start of this century; development was then interrupted by the Spanish Civil War and subsequent short-sighted government policies, only resuming in the 1950's.

Cambridge Studies in Modern Economic History 2 49630-6 Hardback \$59.95

\section{Agricultural Revolution in} England

The Transformation of the Agrarian Economy 1500-1850

\section{Mark Overton}

This survey of English agriculture describes farming in the loth century, analyzes the reasons for improvements and examines changes in the agrarian economy and society.

Cambridge Studies in Historical Geography 23

24682.2 Hardback \$54.95

56859-5 Paperback \$19.95

\section{Industrial Constructions}

The Sources of German Industrial Power

\section{Gary Herrigel}

This book is about the way in which industrial production in Germany was conditioned by social, political, and regional factors from the 17 th century to the present. It suggests that Germany does not have a single coherent national system of industrial governance.

Structural Analysis in the Social Sciences 9

46273-8 Hardback \$54.95

\section{Organised Capital}

Employers' Associations and Industrial Relations in Northern England

\section{Arthur Mclvor}

Using previously untapped primary sources, this derailed study explores employers' organizations from a regional, compararive perspective, analyzing their growth and activities during their heyday, and challenging current interpretations of employers' groups. 55094-7 Hardback \$59.95

\section{Available in UNIVERSITY PRESS}

40 West 20th Street, New York, NY 10011-4211 Call toll-free 800-872-7423.

Web site: http://www.cup.org

MasterCard/VISA accepted. Prices subject to change.

\section{CAMBRIDGE UNIVERSITY PRESS}

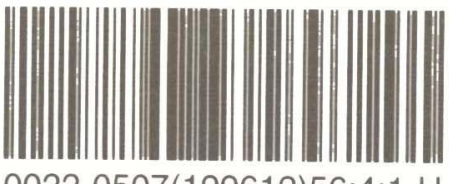

